\title{
TWO-DIMENSIONAL ANALYSIS OF SKIM MILK PROTEINS USING PREPARATIVE ISOELECTRIC FOCUSING FOLLOWED BY POLYACRYLAMIDE GEL ELECTROPHORESIS
}

\author{
HYE-HYUN Y. KIM and RAFAEL JIMENEZ-FLORES
}

\begin{abstract}
A preparative isoelectric focusing (IEF) method was applied to separate skim milk proteins using the Rotofor device in a pH 3-10 gradient containing $4 \mathrm{M}$ urea/1\% triton X-100. Each of the 20 fractions obtained from the Rotofor device was then analyzed by polyacrylamide gel electrophoresis (PAGE). Both ureaPAGE and SDS-PAGE were used to separate purified caseins and skim milk resulting in comparable two-dimensional patterns. The major bovine caseins $\left(\alpha_{\mathrm{s} 1}\right.$, $\alpha_{\mathrm{s} 2}, \beta, k$-casein) were resolved better on urea-PAGE. The $\alpha_{\mathrm{s} 1}$ - and $\beta$-casein were

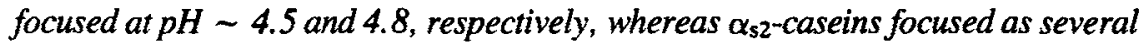
bands at pH 6.2-6.8. The $A$ variant of $k$-casein focuses at Fractions 6-9 which is slightly more acidic than the $B$ variant that focuses at Fractions $7-13$. No sample pretreatment was necessary to analyze skim milk proteins and urea-PAGE clearly resolved bands of all major caseins and whey proteins. Preparative isoelectric focusing followed by PAGE was found to be a useful and powerful method to analyze milk proteins in two-dimensions. This technique facilitates the analysis of the relative amounts of proteins in milk, as well as simplifies the detection of changes and foreign proteins in milk.
\end{abstract}

\section{INTRODUCTION}

Analysis of milk proteins has been extensively carried out by electrophoresis on starch- or polyacrylamide gels (Swaisgood 1975). Recently, high resolution 
two-dimensional electrophoresis has also been used to study milk proteins (TrieuCuot and Gripon 1981, 1982; Shimazaki 1983; Holt and Zeece 1988; Zeece et al. 1989; Marshall and Williams 1988). However, there is still the need for a rapid and reliable method to compare several proteins in different samples simultaneously. Such is the case of comparative studies of the milk proteins of different mammals, or the changes in structure of the milk proteins of different mammals, or the changes in structure of the milk proteins during processing. In the case of proteins produced in the mammary gland of transgenic animals, it is essential to be able to distinguish the heterologous protein from the rest of the proteins in the milk. In addition, it is desirable to assess comparatively the effect of the putative protein on others in the system.

We have developed a two-dimensional technique using preparative isoelectric focusing of the milk proteins as the first dimension. The isoelectric focusing is essentially a type of convection-free electrolysis in which protein molecules are separated on the basis of their isoelectric points (pI) in a pH gradient stabilized by ampholytes. Gradients of broad or narrow $\mathrm{pH}$ can be obtained by varying the composition of acidic and basic low-molecular weight ampholytes (Evans $e t$ al. 1989). Siebert et al. (1985) and Bovenhuis and Verstege (1989) have reported simultaneous separation of casein and whey protein genetic variants by isoelectric focusing.

The Rotofor cell, which is a free solution, isoelectric focusing instrument (BioRad, Richmond, CA), separates up to $55 \mathrm{ml}$ of protein-ampholyte solution into 20 fractions in approximately $4 \mathrm{~h}$. Each fraction has about $2-3 \mathrm{ml}$ of native protein solution and may contain several milligrams of proteins. This electrofocusing chamber makes narrow bands of focused protein by rotation at $1 \mathrm{rpm}$ around the focusing axis to minimize gravity-induced convection and electroosmosis destabilization of the gradient. This unit has been used to purify several proteins including enzymes and antibodies (Egen et al. 1988; Evans et al. 1989; Wynne and Yada 1991; Petrash et al. 1991), and is considered to be useful for the rapid purification of proteins with high yield. One of the examples for its use in foods is the separation of wheat gluten proteins ( $\mathrm{Ng}$ et al. 1989; Curioni et al. 1990).

The fractions obtained from the preparative scale IEF allows the second dimension of analysis to be of a varied nature. Usually PAGE in its various forms yields very good and reproducible results. Since milk proteins have such a varied nature, it is possible to analyze each of the Rotofor fractions with more than one type of gel. For example, caseins are best resolved in urea containing polyacrylamide gel electrophoresis (urea-PAGE), whey proteins in nondenaturing-PAGE and milk fat globule proteins in SDS-PAGE. Selective purification of a desired protein can also be carried out from the isoelectric fractions using any of the chromatographic methods routinely used for milk proteins. The major advantage of this procedure is the ability to analyze the fractions that contain a given protein of interest, and 
then continue to work with the individual fractions selected after IEF separation.

In this work we report the preparative isoelectric focusing method followed by PAGE applied for the separation of bovine skim milk proteins and purified caseins. Among the many methods developed to purify milk proteins such as various HPLC techniques, we found that this newly developed preparative IEF is especially applicable for comparative studies. Many different milk proteins can be compared simultaneously in many different samples due to the two-dimensional nature of the assay. Preparative IEF has several other advantages such as easy sample preparation, short separation time $(4 \mathrm{~h})$, high resolution, reproducibility and large capacity. Each separated fraction by IEF allows successive PAGE experiments in various forms (urea-, nondenaturing- and/or SDS-), additional steps are required for further purification of a given protein in each fraction.

\section{MATERIALS AND METHODS}

The Rotofor preparative IEF cell, Bio-Lyte carrier ampholyte (pH range 3-10), molecular weight standard, acrylamide, bisacrylamide, ammonium persulfate, TEMED and Coomassie brilliant blue R-250 were purchased from BioRad Laboratories (Richmond, CA). Isoelectric focusing pI markers were purchased from Pharmacia, Inc. (Piscataway, NJ). All chemicals were analytical grade. Milk was obtained from the University of Illinois Dairy Farm.

\section{Milk Protein Preparation}

Skim milk was obtained by separating the fat from whole milk by centrifugation (Sorvall, Model RC 2-B) at $3000 \times \mathrm{g}$ for $10 \mathrm{~min}$ at $4 \mathrm{C}$. The skim milk was filtered through four layers of cheese cloth to remove fat.

Casein was prepared by isoelectric precipitation at $\mathrm{pH} 4.6$ with acetate buffer at room temperature. After centrifugation at $3000 \times \mathrm{g}$ for $10 \mathrm{~min}$ at $4 \mathrm{C}$, the casein pellet was washed twice with acetate buffer, vacuum dried and stored at $-80 \mathrm{C}$.

\section{Preparative Isoelectric Focusing}

A Bio-Rad Rotofor cell was assembled for use according to the manufacturer's instructions (BIO-RAD 1990). Three kinds of samples were analyzed; standard pI marker proteins, acid caseins and skim milk proteins.

Isoelectric focusing $\mathrm{pl}$ markers ( $\mathrm{pH}$ range 3-10) were reconstituted with deionized distilled water. Three vials of $\mathrm{pI}$ markers were mixed with $0.25 \mathrm{ml}(0.2 \%$ $\mathrm{w} / \mathrm{v}$ ) of ampholytes ( $\mathrm{pH}$ range $3-10,40 \% \mathrm{w} / \mathrm{v}$ ) and diluted to $50 \mathrm{ml}$ with $5 \%$ 
glycerol containing $0.5 \%$ Triton $\mathrm{X}-100 /$ Chaps. The anode and cathode solutions were $0.1 \mathrm{M} \mathrm{H}_{3} \mathrm{PO}_{4}$ and $0.1 \mathrm{M} \mathrm{NaOH}$, respectively (for all samples). For better resolution, prefocusing was done for $1 \mathrm{~h}$ before loading the sample. IEF was conducted at $12 \mathrm{~W}$ for $4 \mathrm{~h}$ at $3 \mathrm{C}$ and at equilibrium, the running conditions were $830 \mathrm{~V}$ and $14 \mathrm{~mA}$.

The skim milk $(5 \mathrm{ml})$ was mixed with $45 \mathrm{ml}$ of $4 M$ urea/1\% Triton X-100 containing $1.25 \mathrm{ml}(1 \%, \mathrm{w} / \mathrm{v})$ of ampholytes ( $\mathrm{pH}$ range $3-10,40 \% \mathrm{w} / \mathrm{v})$ and 2.5 $\mathrm{ml}$ glycerol, and applied to the Rotofor cell. IEF was run at $12 \mathrm{~W}$ constant power for $5 \mathrm{~h}$ at $4 \mathrm{C}$. At equilibrium, the voltage was $1090 \mathrm{~V}$ and current was $11 \mathrm{~mA}$.

Fifty $\mathrm{mg}$ of dried casein were dissolved in $1 \mathrm{ml}$ of $4 \mathrm{M}$ urea containing $1 \%$ Triton X-100 and dialyzed at $4 \mathrm{C}$ against $4 \mathrm{M}$ urea/ $1 \%$ Triton X-100 solution overnight to remove salts. A 49-ml volume of IEF buffer for casein separation was prepared by mixing $1.25 \mathrm{ml}(1 \% \mathrm{w} / \mathrm{v})$ ampholyte solution (pH range $3-10 ; 40 \%$ w/v) with $47.75 \mathrm{ml}$ of $4 M$ urea/ $1 \%$ Triton X-100, and prefocusing was performed for $1 \mathrm{~h}$ at $12 \mathrm{~W}$ constant power. The casein solution was then loaded into the Rotofor cell for focusing and IEF was conducted at $12 \mathrm{~W}$ constant power for $5 \mathrm{~h}$ at $3 \mathrm{C}$. The initial conditions were $660 \mathrm{~V}$ and $18 \mathrm{~mA}$, and at equilibrium the values were $1260 \mathrm{~V}$ and $9 \mathrm{~mA}$, respectively.

\section{Determination of pH Gradient and Protein Concentration}

After IEF, $0.1 \mathrm{ml}$ of each fraction from Rotofor cell was diluted to $2.0 \mathrm{ml}$ with distilled deionized water, and the $\mathrm{pH}$ was measured with a pH meter (Fischer Scientific, Accumet Model 925).

The protein concentration of each fraction was determined by the bicinchoninic acid (BCA) protein-assay procedure (BIO-Rad Lab., Richmond, CA) using standard curves of casein and bovine serum albumin.

\section{Analytical Gel Electrophoresis}

Skim milk protein fractions obtained from preparative isoelectric focusing were separated in a running gel of $\mathrm{T}=10.0 \%, \mathrm{C}=2.55 \%$, and $\mathrm{pH} 8.9$ containing $4 M$ urea where $\mathrm{T}$ and $\mathrm{C}$ represent the total concentration of acrylamide and the amount of cross-linker in monomer mixture, respectively. The stacking gel was made as $\mathrm{T}=4.6 \%, \mathrm{C}=2.55 \%, \mathrm{pH} 6.7$ and contained $4 \mathrm{M}$ urea. One hundred $\mu \mathrm{l}$ of each fraction were mixed with $100 \mu \mathrm{l}$ of a stacking gel buffer containing $6 M$ urea, $20 \mu \mathrm{l} \beta$-mercaptoethanol and $20 \mu \mathrm{l}$ of $0.1 \%$ bromophenol blue. A $40-\mu \mathrm{l}$ sample was applied into each well of gel in a Mini-protean II system (Bio-Rad Lab., Richmond, CA). The electrode chamber buffer ( $\mathrm{pH} \mathrm{8.3,11)} \mathrm{contains} 6 \mathrm{~g}$ of Tris base and $28.8 \mathrm{~g}$ of glycine. The gels were run at $65 \mathrm{~V}$ until each sample entered the running gel, then the voltage was increased to $120 \mathrm{~V}$ until front line 
reached the bottom. For staining all the gels, 0.1\% Coomassie blue in 50\% methanol, $10 \%$ acetic acid were used. For destaining, $40 \%$ methanol $/ 10 \%$ acetic acid was used. For urea-PAGE of acid casein fractions, all the conditions were as same as those for caseins, except that the running gel had $\mathrm{T}=8 \%$.

The casein fractions from IEF were also separated on SDS-acrylamide gel prepared as described by Laemmli (1970). The running gel had $\mathrm{T}=15 \%, \mathrm{C}$ $=2.67 \%, \mathrm{pH} 8.8$ and stacking gel had $\mathrm{T}=4 \%, \mathrm{C}=2.67 \%, \mathrm{pH} 6.8$. The tank buffer (11) contained $3 \mathrm{~g}$ Tris base, $14.4 \mathrm{~g}$ glycine, and $1 \mathrm{~g}$ SDS. Each fraction was mixed with the same volume of the sample buffer containing $10 \mathrm{~m} M$ Tris$\mathrm{HCl}$ buffer (pH 6.8), 1\% SDS, 1\% 2-mercaptoethanol, and 20\% glycerol, then heated for $5 \mathrm{~min}$ in a boiling water bath; $30 \mu \mathrm{l}$ of each sample were loaded into the gel and was run at $15 \mathrm{~mA}$ constant current.

Nondenaturing polyacrylamide gels were used for resolving $\mathrm{pI}$ marker protein fractions from preparative IEF. One hundred $\mu \mathrm{l}$ of each fraction were mixed with $100 \mu \mathrm{l}$ of sample treatment buffer containing $30 \mu \mathrm{l}$ of stacking gel buffer $(\mathrm{pH}$ 6.8 ), $40 \mu \mathrm{l}$ of distilled water, $10 \mu \mathrm{l}$ of $0.1 \%$ bromophenol blue and $20 \mu \mathrm{l}$ of glycerol. The running gel had $\mathrm{T}=15 \%, \mathrm{C}=2.67 \%$ and $\mathrm{pH} 8.9$ and stacking gel had $\mathrm{T}=4 \%, \mathrm{C}=2.67 \%$ and $\mathrm{pH} 6.8$. Tank buffer $(\mathrm{pH} 8.3$ ) contained 3 $\mathrm{g}$ of Tris base and $14.4 \mathrm{~g}$ of glycine per 11 of buffer. With $30 \mu \mathrm{l}$ sample loaded per well, gels were run at $60 \mathrm{~V}$ for stacking gel and at $120 \mathrm{~V}$ for running gel.

TABLE 1.

THE RESULTS OF PREPARATIVE IEF OF STANDARD PI MARKER PROTEINS The $\mathrm{pI}$ values, observed fraction numbers by IEF, and their corresponding $\mathrm{pH}$ values are listed.

\begin{tabular}{l|c|c|c}
\hline Proteins & $\mathrm{pl}$ & \# fraction & $\mathrm{pH}$ \\
\hline Amyloglucosidase & 3.50 & $2,3,4$ & $2.9-3.9$ \\
B-lactoglobulin A & 5.20 & $5,6,7$ & $4.9-5.3$ \\
Bovine carbonic anhydrase B & 5.85 & $7,8,9$ & $5.3-6.7$ \\
Myoglobin, acidic and basic & $6.85,7.35$ & $9-13$ & $6.7-7.6$ \\
Lentil-lectins & $8.15-8.65$ & $11-17$ & $7.1-8.6$ \\
Trypsinogen & 9.30 & $13-19$ & $7.6-9.3$ \\
\hline
\end{tabular}




\section{RESULTS AND DISCUSSION}

\section{Calibration Test}

Standard pI marker proteins [broad range pH (3-10)] were used for the calibration test of our method. Table 1 summarizes the $\mathrm{pI}$ values and $\mathrm{pH}$ of each fraction from the sample of standard marker proteins. These proteins had $\mathrm{pI}$ values in the range of 3.5-9.3 and each was focused at its expected pI (3.7-9.4) in the Rotofor cell, confirming the accuracy of the $\mathrm{pH}$ gradient in the Rotofor cell. Each fraction of the standard proteins were resolved by nondenaturing-PAGE, which is the same system used for analyzing milk proteins. SDS-PAGE was also used to verify the molecular weights of proteins in each fraction (results not shown). We found that this is a reliable procedure to verify the working conditions of preparative isoelectric focusing.

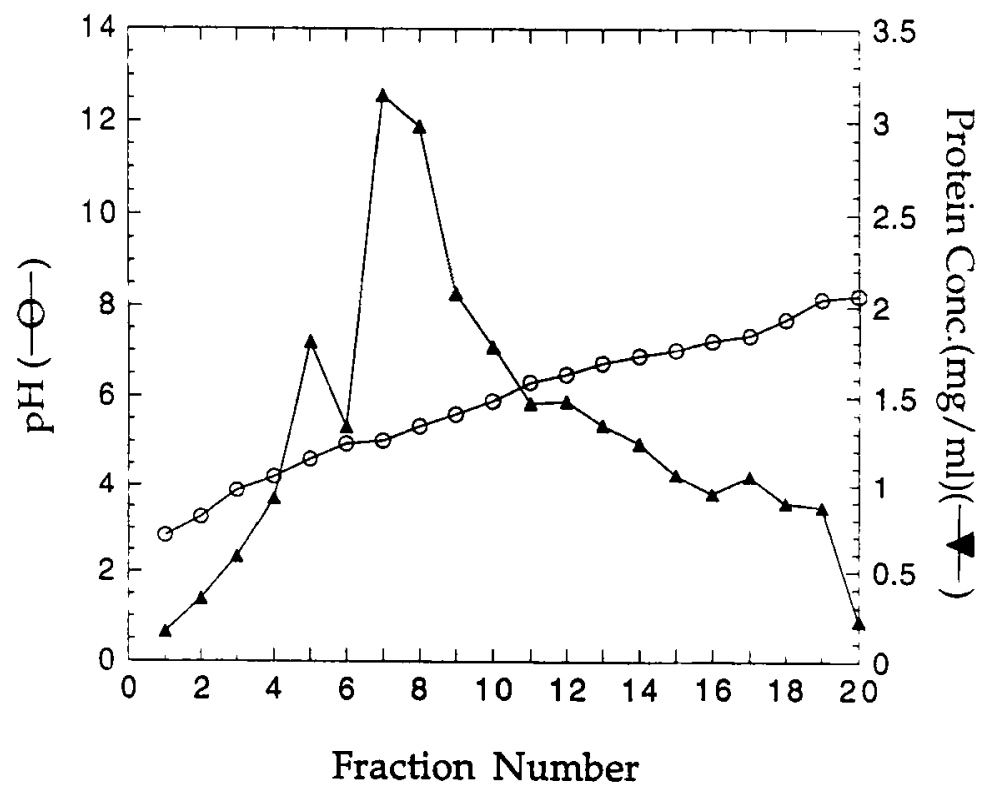

FIG. 1. pH GRADIENT AND PROTEIN CONCENTRATION PROFILE OF BOVINE SKIM MILK PROTEIN FRACTIONS SEPARATED FROM PREPARATIVE IEF Circles represent the $\mathrm{pH}$ value (left) of each fraction. Triangles indicate the total protein concentration of each fraction (right). 


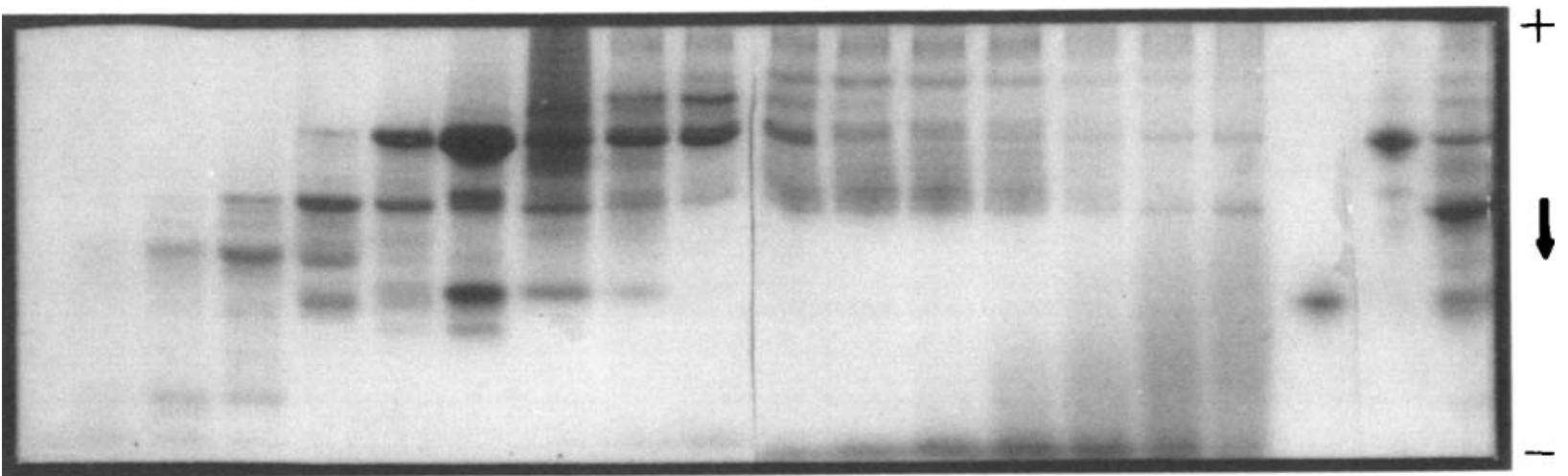

\section{$\begin{array}{lllllllllllllllllllll}1 & 2 & 3 & 4 & 5 & 6 & 7 & 8 & 9 & 10 & 11 & 12 & 13 & 14 & 15 & 16 & 17 & 18 & 19 & 20\end{array}$}

FIG. 2. UREA-PAGE OF SKIM MILK PROTEINS SEPARATED FROM PREPARATIVE IEF

Lanes 1-16 are fractions obtained from preparative IEF; lane 1 corresponds to the acid $\mathrm{pH}$ and 18 to the basic. Lane 7 shows $\alpha$-lactalbumin, $\alpha_{51}$-casein and $\beta$-casein from the bottom. Lane 18 is $\alpha$-lactalbumin, lane 19 is $\beta$-casein and lane 20 is skim milk. 
TABLE 2.

THE PI VALUES AND MOLECULAR WEIGHTS OF SKIM MILK PROTEINS AND NUMBER OF LANES OF ROTOFOR FRACTIONS ON UREA-PAGE (Fig. 1).

\begin{tabular}{l|c|c|c}
\hline Proteins & pI & $\begin{array}{c}\text { M.W. } \\
\text { kD }\end{array}$ & $\begin{array}{c}\text { \# Lanes } \\
\text { in Fig. 1 }\end{array}$ \\
\hline$\alpha_{s 1}$-Casein & $4.2-4.6(a)$ & 23.6 & $4-9$ \\
$\alpha_{\mathrm{s} 2 \text {-Casein }}$ & $4.8-5.1^{(\mathrm{b})}$ & 25.2 & $11-14$ \\
$\beta$-Casein & $4.6-5.1^{(a)}$ & 23.9 & $5-13$ \\
$\kappa$-Casein & $5.3-5.8(a)$ & 19.0 & $9-15$ \\
$\alpha$-Lactalbumin & $4.2-4.5(\mathrm{a})$ & 14.1 & $6-9$ \\
$\beta$-Lactoglobulin & $5.1^{(a)}$ & 18.4 & $3-6$ \\
Serum albumin & $4.7-4.9$ (a) & 66.3 & $9-14$ \\
\hline
\end{tabular}

(a) Based on data from Eigel and Butler (Eigel et al. 1984)

(b) Based on data from Seibert and Erhardt (Seibert et al. 1985)

\section{Skim Milk Proteins}

Figure 1 shows the $\mathrm{pH}$ gradient and protein concentration profile of skim milk proteins. No pretreatment of the skim milk sample was necessary. Most proteins were focused within $\mathrm{pH} 4.2-6.3$, as expected. Urea-PAGE (Fig. 2) shows the resolution of each group of proteins. Table 2 summarizes the properties of milk proteins and the number of the lanes where they were resolved. The $\mathrm{pH}$ range of each protein was not the same as their reported $\mathrm{pI}$ values, possibly due to the influence of salts in milk and/or interactions between proteins in the free-flow system. Caseins were best resolved on urea gels; $\beta$-casein focused in Fractions $5-13$ and mostly concentrated in Fraction $7 ; \alpha_{s 1}$-casein was found in Fractions 4-9; and $\alpha_{\mathrm{s} 2}$-caseins were focused in Fractions 11-14. $\kappa$-Casein was observed as two bands that are shifted; one band in Fractions 9-11 and the other band in Fractions 11-15. Whey proteins were well-resolved by this system; $\alpha$-lactalbumin was focused in Fractions 6-9 and $\beta$-lactoglobulin was in Fractions 3-6. It can be speculated that the separation of whey proteins is influenced by other proteins and ions present in milk. Purified whey proteins have not been successfully separated by their isoelectric points using the conditions described here for 
preparative IEF. However, it is important to mention that when skim milk is focused, the whey proteins are resolved very satisfactorily (Fig. 2). The shift of $\beta$-lactoglobulin from its reported $\mathrm{pl}$ can be due to the dimeric form of $\beta$ lactoglobulin in milk, since running conditions do not allow the reduction of disulfide bridges.

In the process of searching for optimized conditions for milk protein analysis, we examined several buffers to obtain the best separation of proteins during IEF. The most important condition for the preparative IEF buffer is to be nonionic, so as not to decrease the electric resistance, which interferes with the focusing process. We also used a chaotropic reagent to dissociate casein micelles, and a detergent (nonionic or zwitterionic) to prevent precipitation of proteins at their pI. After preliminary tests, we found that $4 M$ urea and $1 \%$ Triton X-100 (v/v) were suitable as a chaotropic agent and as a nonionic detergent, respectively, for solubilizing the proteins. We also found that adding $5 \%$ glycerol $(\mathrm{v} / \mathrm{v})$ in the sample buffer helped maintain the solubility and stability of milk proteins effectively. A benefit of adding glycerol is the increase of the viscosity of the focus-

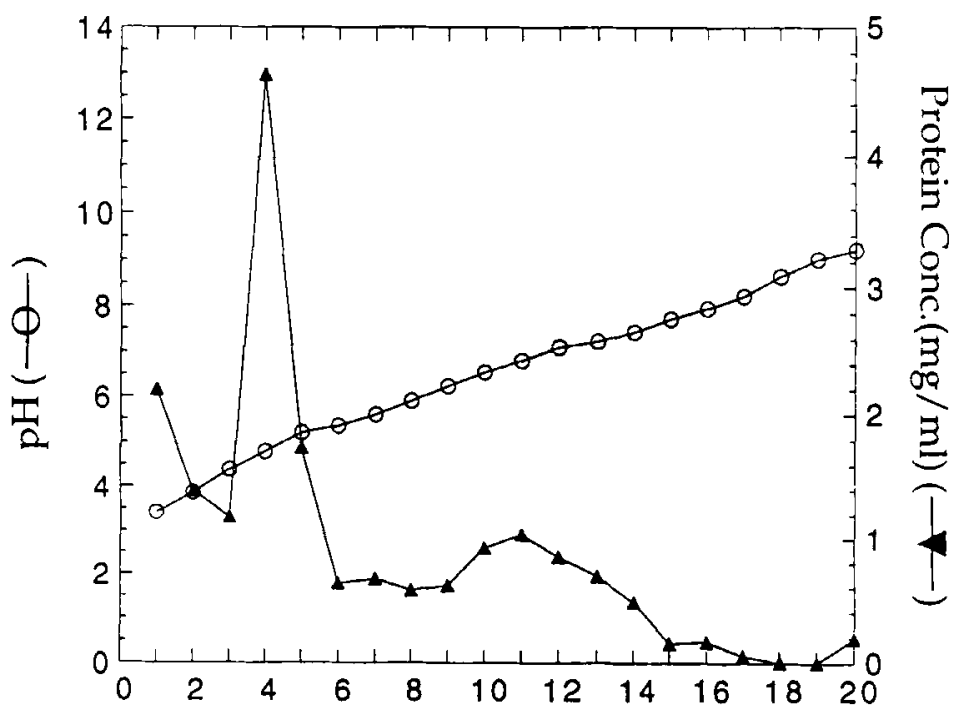

Fraction Number

FIG. 3. pH GRADIENT AND PROTEIN CONCENTRATION PROFILE OF 20 CASEIN FRACTIONS SEPARATED FROM PREPARATIVE IEF

Circles represent the $\mathrm{pH}$ value (left) of each fraction. Triangles indicate the total protein concentration of each fraction (right). 


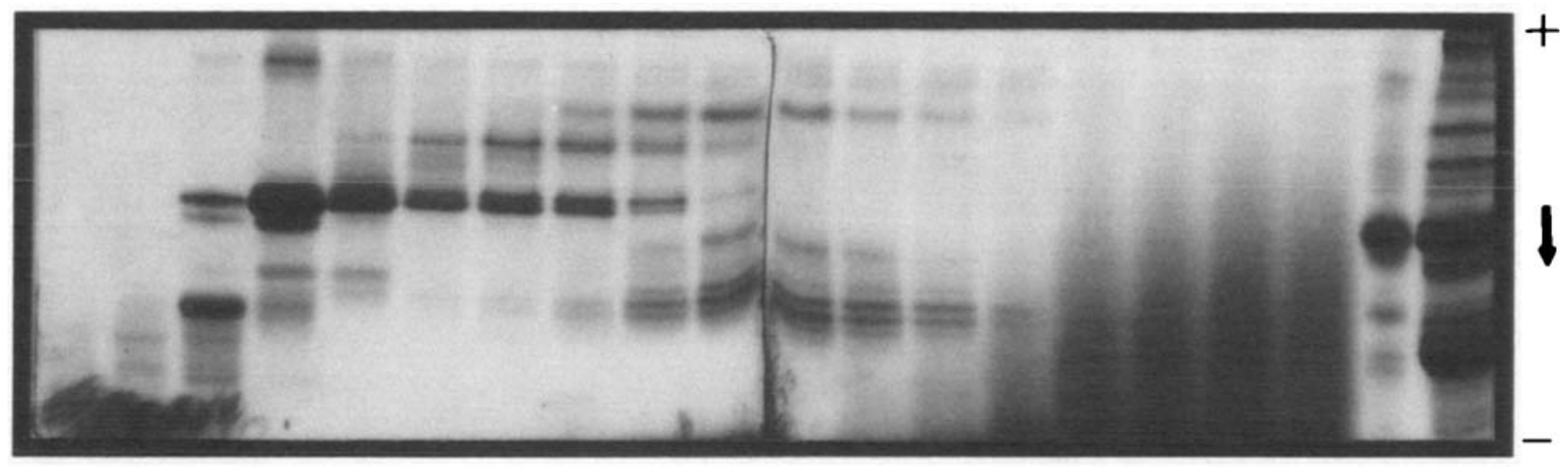

\section{$\begin{array}{llllllllllllllllllll}1 & 2 & 3 & 4 & 5 & 6 & 7 & 8 & 9 & 10 & 11 & 12 & 13 & 14 & 15 & 16 & 17 & 18 & 19 & 20\end{array}$}

FIG. 4(A). UREA-PAGE FOR CASEIN FRACTIONS SEPARATED FROM PREPARATIVE IEF Lanes 1-18 are fractions from preparative IEF; lane 1 corresponds to the acid $\mathrm{pH}$ and 18 to the basic. The major bands on lane 7 are the acidic band of $k$-casein and $\beta$-casein from the bottom. Lane 19 is whole casein and lane 20 is skim milk. 


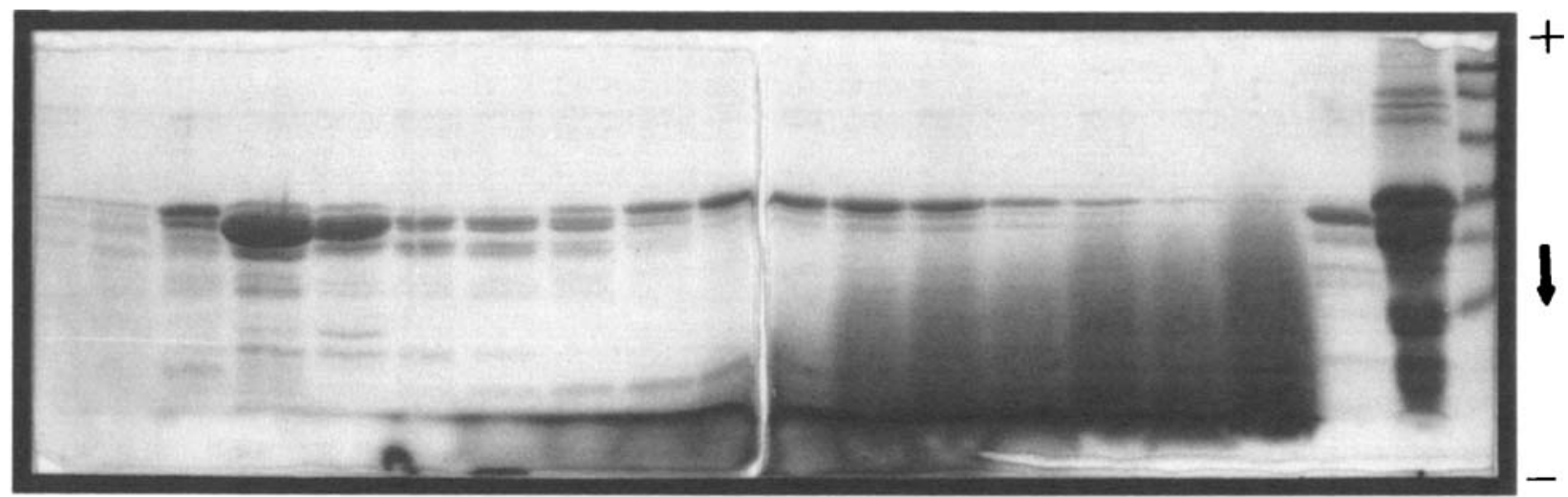

\section{$\begin{array}{llllllllllllllllllll}1 & 2 & 3 & 4 & 5 & 6 & 7 & 8 & 9 & 10 & 11 & 12 & 13 & 14 & 15 & 16 & 17 & 18 & 19 & 20\end{array}$}

FIG. 4(B). SDS-PAGE FOR CASEIN FRACTIONS SEPARATED FROM PREPARATIVE IEF

Lanes 1-17 are 17 fractions obtained from preparative IEF; lane 1 corresponds to the acid $\mathrm{pH}$ and 18 to the basic. The major bands on lane 7 represent $\alpha$-casein and $\beta$-casein from the bottom. Lane 18 is $\beta$-casein, 19 is whole casein and 20 is low molecular weight standard (Bio-Rad) containing 97.4, 66, 45, 31, 21.5 and $14.5 \mathrm{kd}$ proteins. 
ing medium, which helps keep the proteins apart thereby minimizing their interactions (BIO-RAD 1990). Reproducible results are consistently obtained with the mentioned buffer and procedure.

\section{Casein}

The resolutions of two differently prepared milk protein samples have been compared; on the one hand, all the proteins as they exist in skim milk, and on the other caseins that have been precipitated, washed, resuspended, dialyzed and dried. The $\mathrm{pH}$ gradient and protein concentration profile of purified bovine casein fractions obtained by IEF are shown in Fig. 3. Purified casein fractions from the preparative IEF were concentrated at around $\mathrm{pH} 4.8$ and spread over the $\mathrm{pH}$ range 3-9. This center value of $\mathrm{pH} 4.8$ is 0.2 unit $\mathrm{pH}$ higher than expected. This small increase is not surprising, since the presence of urea for preparative IEF leads to a higher apparent isoelectric point than actual pI (Ui 1971; Josephson et al. 1972; Gelsema et al. 1979). Purified caseins contain $\alpha_{\mathrm{s} 1^{-}}, \alpha_{\mathrm{s} 2^{-}}, \beta$ - and $\kappa^{-}$ caseins. Figure 4(a) shows well-resolved typical bands of $\alpha_{\mathrm{s}}$ - and $\beta$-casein on urea gel. They were identified with a $\beta$-casein standard, and agreed with the literature (Van Hekken and Thompson 1992; Medrano and Sharrow 1989). The $\beta$-caseins were well-focused over Fractions 3-10 and mostly concentrated in fraction 4 (pH 4.8).

One of the important separations achieved by this procedure is the clear distinction between $\alpha_{\mathrm{s} 1}$ - and $\alpha_{\mathrm{s} 2}$-caseins (Fig. 4). Under normal urea-PAGE, it is known to be difficult to separate these caseins due to their similar mobilities on the gel. However, addition of the IEF dimension prior to urea-PAGE yields two distinct fractions; $\alpha_{\mathrm{s} 1^{-}}$at $\mathrm{pH} \sim 4.5$ (Fraction 3 ) and several bands corresponding to $\alpha_{\mathrm{s} 2}$-casein at $\mathrm{pH} 6.2-6.8$. These $\alpha_{\mathrm{s} 2}$-caseins are mostly concentrated in Fractions 9-14. The $\alpha_{\mathrm{s} 2}$-caseins have not been well-characterized with respect to their $\mathrm{pI}$ or their behavior in a free-flow isoelectric field, therefore further characterization of these separated $\alpha_{\mathrm{s} 2}$-bands would be very interesting and necessary. $\kappa$ Casein, which is also heterogeneous because of its variable carbohydrate composition (Trieu-Cout 1981), appeared as two bands on the urea gel; one band at slightly acidic pH (Fractions 6-9) and the other band at more basic pH (Fractions 7-13). These bands are considered to correspond to genetic variants $A$ and $B$ of $k$-caseins.

SDS-PAGE has also been used for the casein fractions from preparative IEF and the results are shown in Fig. 4(B). The proteins were tentatively identified by comparison with standard $\beta$-casein, and the results agreed with those reported in the literature (Basch et al. 1985). This gel was used to verify the apparent molecular weights of caseins. The pattern of resolved proteins is the same as that on the urea gel; most of $\beta$-caseins were concentrated in the Fractions 3-9, one 
of the $\alpha_{\mathrm{s}}$-caseins was in Fractions 3-5, and the other was mostly in Fractions 9-14. However, due to the similar molecular weights of $\alpha_{\mathrm{s}^{-}}, \beta$ - and $\kappa$-caseins, and to the fact that caseins run anomolously on SDS-polyacrylamide gels, caseins were resolved better in urea-gel.

Figure 2 represents the separation obtained in skim milk proteins and Fig. 4(a) represents the separation of purified caseins. This two figures show comparable patterns with some minor differences. Both results show similar separation of caseins, even though individual bands of caseins were shown more clearly in the purified casein gel. Fewer bands are apparent in Fig. 4 due to the absence of whey proteins, and in general the higher resolution and $\mathrm{pH}$ gradient differences are a direct result of the missing proteins and salts present in milk. Results of this comparison indicate that the separation of proteins in the preparative IEF is affected by the components in the protein solution. Variations in the $\mathrm{pH}$ gradients, as well as the fraction number in which protein focus, are mainly due to the interactions between the different proteins present and the ionic strength of the buffer used. In general, the patterns of both proteins in skim milk and the purified caseins result in minor variations in the two dimensional patterns. These variations do not preclude the identification of each group of proteins. It is clear that the lower the number of proteins in the sample, the better are the results from this type of free flow IEF. However, the ease of sample preparation and the fact that the numerous proteins can be analyzed when studying the overall pattern of milk proteins, make this technique very attractive in many comparative studies. This technique is especially suitable for computerized image analysis of different patterns of proteins.

\section{CONCLUSION}

Preparative IEF followed by PAGE was found to be very useful for the analysis of all the proteins in skim milk and especially the caseins. The separation of skim milk is very attractive for the analysis of milk proteins due to the simple preparation of the sample for preparative IEF; skim milk can be loaded to the Rotofor cell without any purification, concentration or derivatization. This may be a very important characteristic in the analysis of protein function. This method has combined advantages of high resolution in IEF and large capacity of separation in preparative scale. Using this method we observed good separation between $\alpha_{\mathrm{s} 1^{-}}$ and $\alpha_{\mathrm{s} 2}$-caseins, two separate bands in $\kappa$-casein which are considered to be the genetic variants $A$ and $B$. Additionally, application of this method for skim milk analysis showed that the whey proteins, $\alpha$-lactalbumin and $\beta$-lactoglobulin, can be analyzed in individual fractions from the Rotofor. The capability of simultaneous separation of all the component proteins in milk using initially 
preparative IEF was found to be especially useful for comparative studies on several proteins. In our laboratory, this method has been used to investigate the effect of heating on the proteins in whole milk, to monitor the change of proteins in bovine mammary secretions during the dry period, and to analyze heterologous proteins in the milk of transgenic animals.

\section{ACKNOWLEDGMENT}

This work was supported by the National Dairy Research and Promotion Board and by the Agricultural Experiment Station and Campus Research Board of the University of Illinois.

\section{REFERENCES}

BASCH, J.J., DOUGLAS, F.W.J., PROCINO, L.G., HOLSINGER, V.H. and FARREL, H.M. 1985. Quantitation of caseins and whey proteins of processed milks and whey protein concentrates: application of gel electrophoresis and comparison with Harland-Ashworth procedure. J. Dairy Sci. 68, 23-31.

BIO-RAD. 1990. Rotofor Cell Instruction Manual. Bio-Rad Laboratories, South Richmond, California.

BOVENHUIS, H. and VERSTEGE, A.J.M. 1989. Improved method for phenotyping milk protein variants by isoelectric focusing using PhastSystem. Neth. Milk Dairy J. 43, 447-451.

CURIONI, A., PERUFFO, A.D.B. and POGUA, N.E. 1990. Preparative isoelectric focusing of reduced wheat gluten proteins. Electrophoresis 11, 462-467.

EGEN, N.B., BLISS, M., MAYERSOHN, M., OWENS, S.M., ARNOLD, L. and BIER, M. 1988. Isolation of monoclonal antibodies to phencyalidine from ascites fluid by preparative isoelectric focusing in the Rotofor. Anal. Biochem. $172,488-494$.

EIGEL, W.N., BUTLER, J.E., ERNSTROM, C.A., FARRELL, H.M., HARWALKAR, V.R., JENNESS, R. and WHITNEY, R.M. 1984. Nomenclature of proteins of cow's milk: 5th revision. J. Dairy Sci. 67, 1599-1631.

EVANS, C.H., WILSON, A.C. and GELLERI, B.A. 1989. Preparative isoelectric focusing in ampholine electrofocusing columns versus immobiline polyacrylamide gel for the purification of biologically active leukoregulin. Anal. Biochem. 177, 358-363.

GELSEMA, W.J., DELIGNY, C.L. and VAN DER VEEN, N.G. 1979. Isoelectric points of proteins, determined by isofocusing in the presence of urea and ethanol. J. Chromatog. 17l, 171-181. 
HOLT, D. and ZEECE, M.G. 1988. Two-dimensional electrophoresis of bovine milk proteins. J. Dairy Sci. 71, 2044-2050.

JOSEPHSON, R.V., MIKOLAJCIK, E.M. and SINGH, V.K. 1972. Isoelectric focusing of bovine colostrum immunoglobulins. J. Dairy Sci. 55, 1050-1057.

LAEMMLI, U.K. 1970. Change of structural proteins during the assembly of the head of bacteriophage T4. Nature (London) 227, 680-685.

MARSHALL, T. and WILLIAMS, K.M. 1988. High resolution two-dimensional electrophoresis and sodium dodecyl sulfate-polyacrylamide gel electrophoresis of cheese proteins after rapid solubilization. Electrophoresis 9, 143-147.

MEDRANO, J.F. and SHARROW, L. 1989. Milk protein typing of bovine mammary gland tissue used to generate a complementary deoxyribonucleic acid library. J. Dairy Sci. 72, 3190-3196.

NG, P.K.W., SLOMINSKI, E., JOHNSON, W.J. and BUSHUK, W. 1989. A new perspective on glutenin structure based on fractionation by free-flow preparative isoelectric focusing. Cereal Chem. 66(6), 536-537.

PETRASH, J.M., DELUCAS, L.J., BOULING, E. and EGEN, N. 1991. Resolving isoforms of aldose reductase by preparative isoelectric focusing in the Rotofor. Electrophoresis 12, 84-90.

SEIBERT, B., ERHARDT, G. and SENFT, B. 1985. Procedure for simultaneous phenotyping of genetic variants in cow's milk by isoelectric focusing. Animal Blood Groups Biochem. Genetics 16, 183-191.

SHIMAZAKI, K., TEXIMA, S. and SUKEGAWA, K. 1983. Analysis of bovine whey protein components by two-dimensional electrophoresis. Agric. Biol. Chem. 47(12), 2902-2912.

SWAISGOOD, H.E. 1975. Methods of gel electrophoresis of milk proteins. American Dairy Science Association, Champaign, IL.

TRIEU-CUOT, P. and GRIPON, J.-C. 1981. Electrofocusing and twodimensional electrophoresis of bovine caseins. J. Dairy Res. 48, 303-310.

TRIEU-CUOT, P. and GRIPON, J.-C. 1982. A study of proteolysis during camembert cheese ripening using isoelectrofocusing and two-dimensional electrophoresis. J. Dairy Res. 49, 501-510.

UI, N. 1971. Isoelectric points and conformation of proteins. 1. Effect of urea on the behavior of some proteins in isoelectric focusing. Biochim. Biophys. Acta. 229, 567-581.

VAN HEKKEN, D.L. and THOMPSON, M.P. 1992. Application of PhastSystem to the resolution of bovine milk proteins on urea-polyacrylamide gel electrophoresis. J. Dairy Sci. 75, 1204-1210.

WYNNE, M.G. and YADA, R.Y. 1991. Isolation of Mucor miehei and $M$. pusillus aspartic proteinases from partially purified sources using preparative isoelectric focusing. J. Food Biochem. 15, 347-366.

ZEECE, M.G., HOLT, D.L., WEHLING, R.L., LIEWEN, M.B. and BUSH, L.R. 1989. High-resolution two-dimensional electrophoresis of bovine caseins. J. Agric. Food Chem. 37, 378-383. 